\title{
Leaching of the S-metolachlor herbicide associated with paraquat or glyphosate in a no-tillage system ${ }^{1}$
}

\author{
Anderson Luis Nunes ${ }^{2}$, Ribas Antonio Vidal ${ }^{3}$
}

\section{ABSTRACT}

The combined use of desiccant and residual herbicides is a common management practice under no-tillage systems. However, the effect of desiccant herbicides and mulch on the leaching of residual herbicide is unknown. This study aimed at assessing the leaching of the S-metolachlor herbicide applied to ryegrass sequentially or in association with paraquat or glyphosate. A randomized blocks design was used, with four repetitions and treatments distributed over split-plots. The desiccant herbicides paraquat $\left(600 \mathrm{~g} \mathrm{ha}^{-1}\right)$ or glyphosate $\left(720 \mathrm{~g} \mathrm{ha}^{-1}\right)$ were used in the main plot, while S-metolachlor $\left(2,800 \mathrm{~g} \mathrm{ha}^{-1}\right)$ was applied sequentially or in association with the desiccant herbicides in the subplots. There was also a control containing only desiccant herbicide, with no application of residual herbicide. The type of desiccant did not affect the leaching of the residual herbicide. In addition, the chosen method to apply the residual herbicide, sequentially or in association with the desiccant, did not impact the S-metolachlor behavior in the soil. The bioavailable concentration in the soil, 25 days after the application, was $90 \mathrm{~g}$ a.i. ha ${ }^{-1}$, at a depth of $18 \mathrm{~cm}$.

KEY-WORDS: Lolium multiflorum; bioassay; percolation; residual herbicide; plant cover.

\section{INTRODUCTION}

The combined use of residual herbicides and glyphosate to manage plant cover for crop establishment is increasingly common in no-tillage systems. The use of residual herbicides improves weed control during early crop growth and is an alternative for controlling herbicide-resistant weeds (Zemolin et al. 2014). However, the presence of plant cover on the soil at the application time causes changes that affect the dynamics of residual herbicides (Cassigneul et al. 2015).

\section{RESUMO}

Lixiviação do herbicida S-metolachlor associado a paraquat ou glyphosate em plantio direto

A associação de herbicidas dessecantes com herbicidas residuais constitui manejo comum, em áreas sob semeadura direta. Entretanto, não se conhece o efeito do herbicida dessecante e da palhada sobre a lixiviação do herbicida residual. Objetivou-se determinar a lixiviação do herbicida S-metolachlor, aplicado sequencialmente ou associado a paraquat ou glyphosate, sobre azevém. Utilizou-se delineamento em blocos casualizados, com quatro repetições, sendo os tratamentos distribuídos em parcelas subdivididas. Nas parcelas principais, foram alocados os herbicidas dessecantes paraquat $\left(600 \mathrm{~g} \mathrm{ha}^{-1}\right)$ ou glyphosate $\left(720 \mathrm{~g} \mathrm{ha}^{-1}\right) \mathrm{e}$, nas subparcelas, S-metolachlor $\left(2.800 \mathrm{~g} \mathrm{ha}^{-1}\right)$ aplicado sequencialmente ou associado aos herbicidas dessecantes, assim como uma testemunha contendo apenas herbicida dessecante, sem aplicação do herbicida residual. O tipo de herbicida dessecante não interferiu na lixiviação do herbicida residual. Além disso, a modalidade de aplicação do herbicida residual, sequencialmente ou em associação ao dessecante, não afetou o comportamento do S-metolachlor no solo. A concentração biodisponível no solo, aos 25 dias após a aplicação, foi de $90 \mathrm{~g}$ i.a. ha-1 ${ }^{-1}$ à profundidade de $18 \mathrm{~cm}$.

PALAVRAS-CHAVE: Lolium multiflorum; bioensaio, percolação; herbicida residual; cobertura vegetal.

The presence of plant cover may inhibit herbicide leaching, due to the interception and sorption of components in the plant cover. The atrazine herbicide shows less leaching in a no-tillage system, when compared to conventional tillage (Weber et al. 2006b), likely due to the fact that the plant cover exhibits greater sorption capacity than the soil.

The association with a desiccant may also affect the leaching dynamics of residual herbicides, since S-metolachlor is less persistent in the presence of glyphosate, if compared to paraquat (Nunes \&

1. Manuscript received in Mar./2016 and accepted for publication in Aug./2016 (http://dx.doi.org/10.1590/1983-40632016v4640405).

2. Instituto Federal do Rio Grande do Sul, Campus Sertão, Sertão, RS, Brazil.E-mail: anderson.nunes@sertao.ifrs.edu.br.

3. Universidade Federal do Rio Grande do Sul, Faculdade de Agronomia, Departamento de Plantas de Lavoura, Porto Alegre, RS, Brazil.E-mail: ribas.vidal@ufrgs.br. 
Vidal 2008). Low persistence means that there is likely less leaching, since the time required in the soil for leaching to occur is shorter. In addition, chemical reactions may occur between the residual herbicide and desiccant, potentially affecting the leaching of S-metolachlor.

S-metolachlor is a nonionizable compound that belongs to the acetamides chemical group. It has been applied as a preemergent or preplant incorporated herbicide to control monocots and dicots, acting to selectively inhibit shoots of maize (Arantes et al. 2014), soybean (Steckel et al. 2015), cotton (Barroso et al. 2012) and sorghum crops, via association with herbicide safeners (Silva et al. 2014).

Metolachlor is formed by an R-isomer and $\mathrm{S}$-isomer pair, present in the herbicide in equal proportions. The S-isomer pair is more active on weeds than the R-isomer pair. This knowledge prompted the development of a new catalytic system that produces a novel substance enriched (>80\%) with S-isomers, denominated S-metolachlor (Senseman 2007).

In general, it is known that the leaching of metolachlor depends on factors such as the occurrence and intensity of rainfall or irrigation, temperature and soil surface area, as well as humic acid, clay and organic matter content in the soil (Patakioutas \& Albanis 2002, Weber et al. 2006a, Baran \& Gourcy 2013, Long et al. 2014). However, mathematical models demonstrate that metolachlor has leaching potential (Inoue et al. 2003). Under field conditions, research has shown different levels of leaching for this herbicide. In soil with $5.7 \%$ of organic matter, $90 \%$ of the metolachlor applied is concentrated in the first $10 \mathrm{~cm}$. By contrast, over $45 \%$ of the product are found at more than $30 \mathrm{~cm}$ below the surface, in soil with $0.9 \%$ of organic matter.

This study aimed at assessing the leaching of the residual herbicide S-metolachlor, when applied to ryegrass sequentially or in association with desiccant herbicides.

\section{MATERIAL AND METHODS}

Two experiments were conducted at the Universidade Federal do Rio Grande do Sul, in 2008. The first experiment was conducted in the field, where herbicides were applied and soil columns were subsequently collected for leaching analysis. The second experiment was conducted in a growth chamber, where the plant indicator (Raphanus sativus L.) was planted across the soil columns, to quantify S-metolachlor in the soil. The field experiment was conducted in soil classified as a typical dystrophic Ultisol (Embrapa 2006) containing $2.3 \%$ of organic matter and $28 \%$ of clay. A randomized blocks design was used, with four repetitions and experimental units measuring $2 \mathrm{~m}$ x $5 \mathrm{~m}$. Treatments were distributed over splitplots. The desiccant herbicides paraquat $\left(600 \mathrm{~g} \mathrm{ha}^{-1}\right)$ or glyphosate $\left(720 \mathrm{~g} \mathrm{ha}^{-1}\right)$ were used in the main plot and S-metolachlor $\left(2,800 \mathrm{~g} \mathrm{ha}^{-1}\right)$ was applied sequentially or in association with the desiccants in the subplots. There was also a control containing only the desiccants, with no application of the residual herbicide. Sequential application was performed at 5 min after desiccation.

The herbicides were sprayed using a spray volume of $110 \mathrm{~L} \mathrm{ha}^{-1}$ and a $\mathrm{CO}_{2}$ - pressurized backpack sprayer, with a constant pressure of $200 \mathrm{kPa}$ and TeeJet 8001 spray nozzles spaced $0.50 \mathrm{~m}$ apart, on a $1.5 \mathrm{~m}$ long boom. Applications were performed between 4 p.m. and 4:55 p.m., when the mean temperature and relative humidity were $27{ }^{\circ} \mathrm{C}$ and $71 \%$, respectively. The herbicides were applied to live plant cover consisting of flowering Lolium multiflorum Lam. plants. The total dry mass of the plant cover was $2,800 \mathrm{~kg} \mathrm{ha}^{-1}$. Rainfall was measured using a rain gauge installed in the study area (Figure 1).

The soil samples used to assess leaching were collected at 25 days after the application (DAA) of herbicides in the field. This period was chosen for sample collection to allow sufficient rainfall

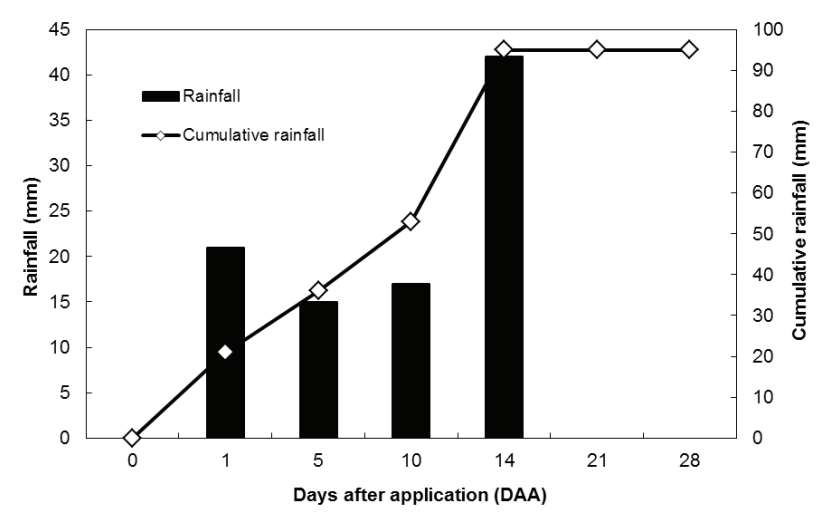

Figure 1. Rainfall and cumulative rainfall between the herbicide application and soil column collection. 
for herbicide percolation. First, plant material was removed from the surface of the soil and a PVC tube (25 cm long x $25 \mathrm{~mm}$ wide) was inserted, using a rubber hammer, until the end of the tube was in line with the soil surface. Next, the tubes were removed without disturbing the soil samples and placed in polystyrene boxes. The upper third of the tube was cut horizontally, using a table saw, in order to plant the plant indicator.

Next, a bioassay was carried out in a growth chamber, using Raphanus sativus L. (common radish) as a bioindicator of S-metolachlor leaching. Pre-germinated seeds were sown every $2 \mathrm{~cm}$ across the soil column collected in the $2-18 \mathrm{~cm}$ soil layer. The plants were grown under a mean temperature of $25.3 \pm 3.1{ }^{\circ} \mathrm{C}$ and relative humidity of $85.4 \pm$ $9.8 \%$, with a $12 \mathrm{~h}$ photoperiod and sprinkler irrigation. Phytotoxicity was assessed at 7 days after planting (DAP), using the plant indicators in the soil samples. Toxicity values ranged from $0 \%$ (no effect on the plant) to $100 \%$ (lethal effect). The bioindicator (common radish) height was evaluated at 11 DAP, using a ruler.

The radish height results were used to determine the bioavailability of S-metolachlor in the soil. The bioavailability of this herbicide was measured using a calibration curve $(97.05-1.02 \mathrm{x}+$ $\left.0.0035 \mathrm{x}^{2} ; \mathrm{R}^{2}=0.93 ; \mathrm{p} \geq 0.01\right)$ constructed at the same time and under the same conditions as the bioassay of Nunes \& Vidal (2008). Data obtained in the bioassay were converted into percentages, in relation to the control without the residual herbicide. Data were submitted to analysis of variance, using the F-test. The means of the variables were compared using the least significant difference (LSD) approach at $5 \%$ $(p \geq 0.05)$.

\section{RESULTS AND DISCUSSION}

Statistical analysis found no significant effect for the desiccants (paraquat and glyphosate), application (combined and sequential) or any of the possible interactions. As such, the results for the effects of depth are shown in the means for the types of application.

The radish plant indicators exhibited low toxicity symptoms at $7 \mathrm{DAP}$, when planted in soil permeated with S-metolachlor, at depths between $2 \mathrm{~cm}$ and $16 \mathrm{~cm}$. However, at $18 \mathrm{~cm}$ depth, phytotoxicity was $26 \%$, indicating a higher concentration of S-metolachlor (Figure 2). The phytotoxicity results demonstrate that cumulative rainfall of $95 \mathrm{~mm}$ was sufficient to leach S-metolachlor from the plant cover into depths of the soil, where the product has no herbicidal activity. The weeds seeds are concentrated in the first $5 \mathrm{~cm}$ of soil (Senseman 2007). As such, residual herbicides that percolate below this depth provide low control efficiency.

Radish forage height evaluated at 11 DAP showed taller plants, when grown at $2 \mathrm{~cm}$ and $16 \mathrm{~cm}$ soil depth, if compared to the $18 \mathrm{~cm}$ depth (Figure 3 ). At $18 \mathrm{~cm}$, plants were, on average, $30 \%$ shorter than at other shallower depths. The bioavailability

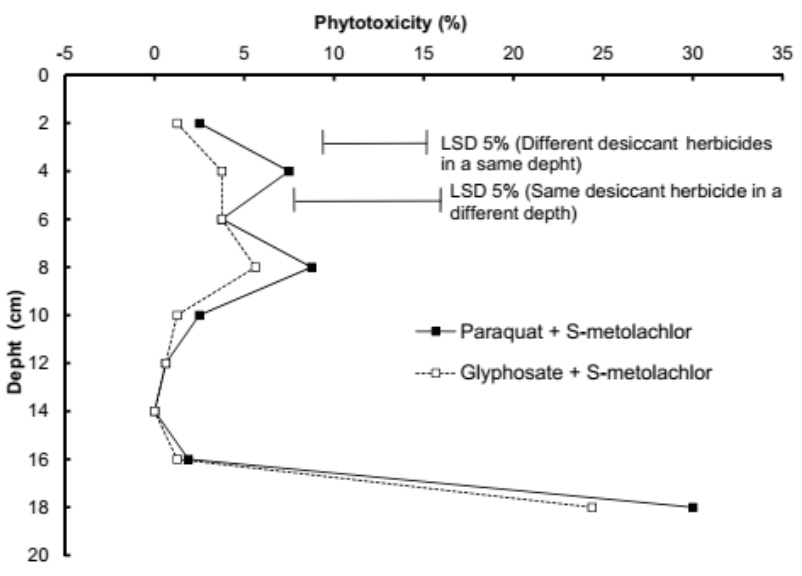

Figure 2. Leaching of S-metolachlor combined with desiccant herbicides (paraquat and glyphosate) at soil depths of 0-20 cm, at 7 DAP. Radish forage toxicity was used as an indicator of S-metolachlor.

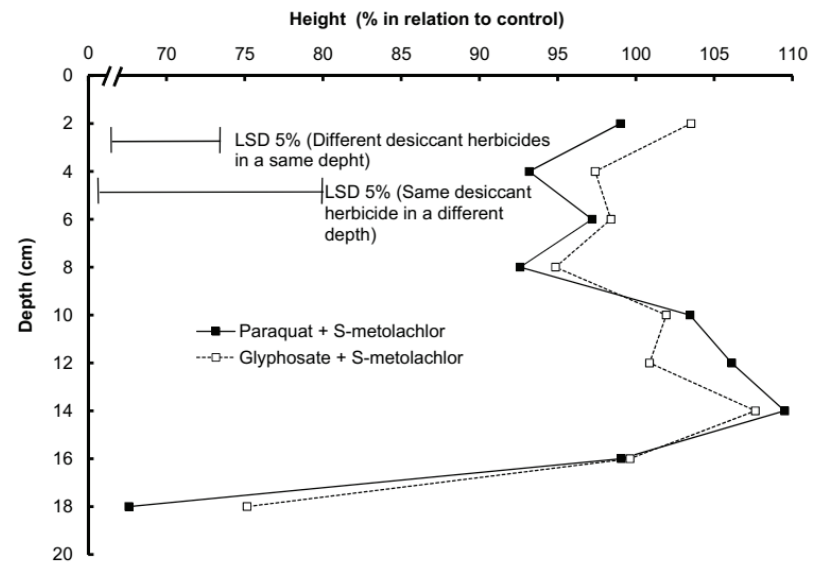

Figure 3. Height (\% in relation to the control) of radish plants, as a function of depth $(0-20 \mathrm{~cm})$ of a soil with the application of S-metolachlor associated with desiccant herbicides (paraquat and glyphosate), at 11 DAP. 
of S-metolachlor in the soil was determined based on the calibration curve $\left(97.05-1.02 \mathrm{x}+0.0035 \mathrm{x}^{2}\right.$; $\left.\mathrm{R}^{2}=0.93 ; \mathrm{p} \geq 0.01\right)$.

Bioavailability did not differ from $2 \mathrm{~cm}$ to $16 \mathrm{~cm}$ depths, with mean S-metolachlor availability of $77 \mathrm{~g} \mathrm{ha}^{-1}$. However, at $18 \mathrm{~cm}$, bioavailability differed from the other depths assessed, with $89 \mathrm{~g} \mathrm{ha}^{-1}$ of S-metolachlor. Of the $2,800 \mathrm{~g} \mathrm{ha}^{-1}$ of S-metolachlor initially applied in the field, $705 \mathrm{~g} \mathrm{ha}^{-1}(31 \%)$ was bioavailable in the soil, when assessed at 25 DAA (Figure 4).

Based on the variables analyzed (phytotoxicity and height) and by estimating bioavailability, it was found that S-metolachlor was more concentrated at a depth close to $18 \mathrm{~cm}$, when exposed to cumulative rainfall of $95 \mathrm{~mm}$, over 25 days. Leaching of metolachlor was thought to be insignificant, when the soil organic matter content was $2.0 \%$ (Senseman 2007). However, the organic matter content in the soil used here was $2.3 \%$, in a soil with $28 \%$ of clay.

In the soil with $1.5 \%$ of organic matter and $33 \%$ of clay, metolachlor was detected at depths of up to $10 \mathrm{~cm}$, when submitted to $33 \mathrm{~mm}$ of water, but did not move beyond $5 \mathrm{~cm}$, when exposed to $20 \mathrm{~mm}$ of water (Vieira et al. 2003).

In another soil type, containing $0.94 \%$ of organic matter and $7.3 \%$ of clay, metolachlor reached a depth of $30 \mathrm{~cm}$, with $13 \mathrm{~mm}$ of water (Barnes et al. 1992). The mobility of metolachlor is inversely related to the organic matter and clay content of the soil (Singh et al. 2002).

The main determining factors for pesticide leaching in soil are the water solubility of the molecule, soil texture and structure, and the rainfall

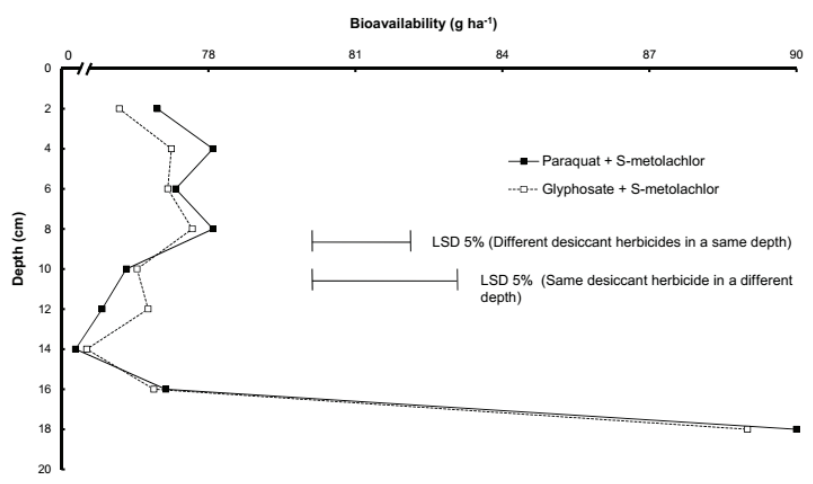

Figure 4. Bioavailability of S-metolachlor, as a function of desiccants (paraquat and glyphosate) obtained using the height of radish plants measured at 11 DAP, for soil depths of $0-20 \mathrm{~cm}$. levels in the area (Lavorenti et al. 2003). Thus, the high water solubility of S-metolachlor (488 $\mathrm{mg} \mathrm{L}^{-1}$ ) and cumulative rainfall of $95 \mathrm{~mm}$ may explain the leaching of S-metolachlor. Analysis of S-metolachlor content in the soil ( $0-18 \mathrm{~cm}$ depth) showed that only $25.2 \%$ of the product initially applied was available in the soil solution (Figure 4).

There are four possible explanations for the low bioavailability observed: 1 ) due to a rapid degradation of the herbicide in the environment, as observed by Nunes \& Vidal (2008), who found that the half-life of herbicides varies between 11 and 15 days, as a function of the desiccant herbicide used; 2) part of the molecules may have been adsorbed to colloids in the soil or plant cover (Cassigneul et al. 2015), and thus became unavailable in the soil solution for root absorption by the plant indicator. The log Kow of S-metolachlor is 2.89, exhibiting moderate sorption to colloids in the soil and plant cover (Aslam et al. 2015). However, sorption levels of S-metolachlor rise with the decomposition of plant cover, due to an increase in the external surface area for sorption of the herbicide (Iqbal et al. 2013); 3) the product may have been absorbed by the leaves or roots of the live plant cover; 4) S-metolachlor may have leached to depths greater than $18 \mathrm{~cm}$, since cumulative rainfall was high. In some cases, this herbicide was detected at depths of up to $1 \mathrm{~m}$ and at concentrations of $0.230 \mu \mathrm{g} \mathrm{L}^{-1}$ (Marín-Benito et al. 2014).

\section{CONCLUSIONS}

1. The desiccant herbicides paraquat and glyphosate do not affect the leaching of the S-metolachlor residual herbicide. There are no differences in S-metolachlor leaching, as a function of its sequential or combined application with desiccants;

2. The highest concentration of S-metolachlor detected in the bioassay was observed at the highest evaluated depth $(18 \mathrm{~cm})$.

\section{REFERENCES}

ARANTES, J. G. Z. et al. Selectivity of chemical weed control systems in conventional cotton. Planta Daninha, v. 32, n. 4, p. 827-841, 2014.

ASLAM, S. et al. Effect of rainfall regimes and mulch decomposition on the dissipation and leaching of 
S-metolachlor and glyphosate: a soil column experiment. Pest Management Science, v. 71, n. 2, p. 278-291, 2015.

BARAN, N.; GOURCY, L. Sorption and mineralization of S-metolachlor and its ionic metabolites in soils and vadose zone solids: consequences on groundwater quality in an alluvial aquifer (Ain Plain, France). Journal of Contaminant Hydrology, v. 154, n. 1, p. 20-28, 2013.

BARNES, C. J.; LAVY, T. L.; TALBERT, R. E. Leaching, dissipation, and efficacy of metolachlor applied by chemigation or conventional methods. Journal of Environmental Quality, v. 21, n. 2, p. 232-236, 1992.

BARROSO, A. L. D. L. et al. Seletividade de herbicidas aplicados em pré-emergência na cultura do algodoeiro. Bioscience Journal, v. 28, n. 5, p. 762-769, 2012.

CASSIGNEUL, A. et al. Nature and decomposition degree of cover crops influence pesticide sorption: quantification and modelling. Chemosphere, n. 119, p. 1007-1014, 2015.

EMPRESA BRASILEIRA DE PESQUISA AGROPECUÁRIA (Embrapa). Sistema brasileiro de classificação de solos. Rio de Janeiro: Embrapa Solos, 2006.

INOUE, M. H. et al. Critérios para avaliação do potencial de lixiviação dos herbicidas comercializados no Estado do Paraná. Planta Daninha, v. 21, n. 2, p. 313-323, 2003.

IQBAL, A. et al. Tissue density determines the water storage characteristics of crop residues. Plant Soil, v. 367, n. 1-2, p. 285-299, 2013.

LAVORENTI, A.; PRATA, F.; REGITANO, J. B. Comportamento de pesticidas em solos: fundamentos. In: CURI, N. et al. (Ed.). Tópicos especiais em Ciência do Solo. Viçosa: SBCS, 2003. p. 335-400.

LONG, Y. H.; LI, R. Y.; WU, X. M. Degradation of S-metolachlor in soil as affected by environmental factors. Journal of Soil Science and Plant Nutrition, v. 14, n. 1, p. 189-198, 2014.

MARÍN-BENITO, J. M. et al. Comparison of three pesticide fate models with respect to the leaching of two herbicides under field conditions in an irrigated maize cropping system. Science of the Total Environment, n. 499, p. 533-545, 2014.

NUNES, A. L.; VIDAL, R. A. Persistência do herbicida S-metolachlor associado ao glyphosate ou paraquat em plantio direto. Planta Daninha, v. 26, n. 2, p. 385-393, 2008.

PATAKIOUTAS, G.; ALBANIS, T. A. Adsorptiondesorption studies of alachlor, metolachlor, EPTC, chlorothalonil and pirimiphos-methyl in contrasting soils. Pest Management Science, v. 58, n. 4, p. 352-362, 2002.

SENSEMAN, S. A. Herbicide handbook. Lawrence: Weed Science Society of America, 2007.

SILVA, J. R. V. D. et al. Fluxofenim used as a safener on sorghum seed for S-metolachlor herbicide. Bioscience Journal, v. 30, n. 3, p. 158-167, 2014.

SINGH, N.; KLOEPPEL, H.; KLEIN, W. Movement of metolachlor and terbuthylazine in core and packed soil columns. Chemosphere, v. 47, n. 4, p. 409-415, 2002.

STECKEL, L. E.; STEWART, S. D.; STECKEL, S. Corn response to post-applied hppd-inhibitor based premix herbicides with in-furrow and foliar-applied insecticides. Weed Technology, v. 29, n. 1, p. 18-23, 2015.

VIEIRA, R. F.; SILVA, A. A.; RAMOS, M. M. Aplicação de herbicidas pós-emergentes via irrigação por aspersão: revisão. Planta Daninha, v. 21, n. 3, p. 495-506, 2003.

WEBER, J. B.; TAYLOR, K. A.; WILKERSON, G. G. Soil and herbicide properties influenced mobility of atrazine, metolachlor, and primisulfuron-methyl in field lysimeters. Agronomy Journal, v. 98, n. 1, p. 8-18, 2006 a.

WEBER, J. B.; TAYLOR, K. A.; WILKERSON, G. G. Soil cover and tillage influenced metolachlor mobility and dissipation in field lysimeters. Agronomy Journal, v. 98, n. 1, p. 19-25, 2006b.

ZEMOLIN, C. R. et al. Environmental fate of S-metolachlor: a review. Planta Daninha, v. 32, n. 3, p. 655-664, 2014. 